\title{
How Strategic Conformity Interacts with Innovation: An Empirical Study on Korean Manufacturing Firms from the Perspective of Optimal Distinctiveness
}

\author{
Myung Sub Lim ${ }^{\circledR}$, Choo Yeon Kim and Jae Wook Yoo* \\ College of Business Administration, Konkuk University, Seoul 05029, Korea; myungsub.lim@gmail.com (M.S.L.); \\ chookim@konkuk.ac.kr (C.Y.K.) \\ * Correspondence: jwyoo@konkuk.ac.kr
}

Received: 27 August 2020; Accepted: 10 October 2020; Published: 19 October 2020

\begin{abstract}
Whether to have a similar or different strategy than firms in same industry is the fundamental question for firms that want to build a competitive advantage. Recent literature, such as the new institutional theory and the perspective of optimal distinctiveness, has emphasized the configuration of competing forces that make firms simultaneously similar by conforming to industry norms and different by implementing innovation, leading to high performance. The primary rationale is that firms can exploit their high status of conformity as a stock of capital to differentiate themselves when required. Upon this rationale, we conducted research to test the hypotheses for optimal distinctiveness in the strategies of manufacturing firms in Korea. The results show that Korean firms have higher performance when they are mutually involved in higher conformity and innovation. It also suggests that firms in the industry with high volatility have difficulties in managing optimal distinctiveness of strategic conformity with innovation.
\end{abstract}

Keywords: strategic conformity; isomorphism; innovation; optimal distinctiveness; industry dynamism

\section{Introduction}

According to the Fortune 500 survey on firm expectancy, only 61 companies out of 500 appeared in the list both in 1955 and 2016; others went bankrupt, merged, or remained but not in the top of the list [1]. This statement is probably the most precise summary of the Fortune 500 survey on firm expectancy. The implication of this summary is simple. The probability of a firm's success or even survival is getting smaller. Businesses attempted to achieve sustainability at all times. Some succeeded, and others did not. Academicians, as well, have come up with various theories to explain the phenomena and answer the fundamental question-how can firms be competitive for a long time? Observing how firms have been reacting to the changes in the business environment makes it possible to answer this critical question. The answer largely lies in finding and implementing the right strategies, as many best practices have suggested in business history. In addition, it also lies in configuring the correct combination of strategies. However, this is easier said than done for many reasons. The first and, arguably, the most important reason, is related to firms' decisions about how much they conform to the norms and standards in the industry to be homogeneous in strategy with firms in same industry. Further, they must figure out how the strategic position resulted from the company's resource deployment, and various activities would help or deter the outcome of innovation.

The literature on management has presented robust theories and evidence in the research on firm success, but not in a universal stance or perspective. Heterogeneity and homogeneity in the practices are the two main opposing perspectives in explaining firm performance. Many research topics, such as 
industrial organization (IO), resource-based view (RBV), and competitive dynamics, support the concept of "being heterogeneous" [2-5]. Conversely, other fields, such as institutional theory and population ecology, support "being homogeneous" [6,7]. Normative as they are, the different concepts to explain the behaviors of successful firms have brought about some dilemmas for practitioners. Many managers tend to fall into the trap of indecisiveness, that is, whether to focus on following a dominant norm in the industry or create new logic. In this regard, the first research motivation of this study is to explore the impact of strategic conformity (degree of conformity to industry norms and standards) on firm performance in certain surrounding circumstances.

Firms react or proact to the environment for a competitive position. Irrespective of how many conform to the norm in the industry, their involvement with innovation depends on changes in the internal and external environment. From technology-driven new product development to the transformation of business models, there are different kinds of innovation activities. Among many typologies, three pairs of innovation types are most acknowledged: administrative and technical, product and process, and radical and incremental [8]. In terms of which firms innovate, the first two typologies matter and relate to the "outputs" of differentiation. Regarding how firms innovate, the last typology matters most, as it defines the "outcomes" of differentiation; that is, how different from or similar to other firms a firm would be positioned in the industry.

Radical innovation is considered a fundamental departure from existing practices, whil incremental innovation refers to a little departure from the existing practices $[9,10]$. Together, incremental and radical innovation might improve firm performance and success. However, the impact on a firm's strategic positioning in the industry might be different. Regarding the novelty of innovation, when firms with more radical innovations succeed, the more different from others they become. In many cases, if not all, incremental innovation more likely makes a firm similar to other market leaders, and thus, they fall in line with the industry norm. Normally, incremental innovation is used to catch-up with first movers when the difficulties associated with implementing the innovation are reduced. In fact, successful radical innovations are deemed to become the new normal at some point in time. In contrast, incremental innovations are prevalent after the new normal is established before another radical innovation emerges. Thus, in this study, we define innovation as radical actions that help a firm to differentiate itself from its competitors.

Just as the tendency of strategic conformity, resulting in the level of conformity (how homogeneous or heterogeneous) reflects the overall effect of a firm's strategic activities, it is necessary to define innovation as the integrated sum of activities that cannot be reflected by specific functional, innovative activities $[11,12]$. The primary concern is if the innovation activities would be synergistic with low conformity or high conformity in particular surroundings. Historically, scholars have prioritized the "strategic fit" [13-15]. They have argued that internal alignment among the activities would drive better performance. According to this notion, firms with low conformity would perform better when they are involved with radical innovations. However, some of the research streams, such as new institutional theory and optimal distinctiveness, have recently tried to explain firms' competing forces as complementarities that increase performance [16-18]. Thus, the next research motivation of this study is to find out how the strategic conformity (degree of conformity to industry norms and standards) of a firm interacts with its innovation activities.

To further study these two research motivations, we selected one country in which the traditional industry norms and innovation trends are observed in all industries. Korea, as a leading developing country, has developed its national economy through strong legislation and government-led initiation. Recently, though, as a new industry paradigm has emerged, Korean firms have been building another dimension of capabilities-innovation. These two characteristics now co-exist. The research motivations suggest that the Korean manufacturing industry can be explained either by the institutional theory [6] or industrial organization (IO) [2]/resource-based view (RBV) [4] or both (from the literature review of "two opposing theories"). Their behavior must be rational, so we determine why Korean firms in the manufacturing industry lean more toward isomorphic or idiosyncratic processes, and for 
what reasons and under what circumstances. It is also required that we further investigate if the relationship between strategic conformity and the innovation activities and the its impact on the performance of firms can be explained by a specific perspective or theory under certain circumstances.

\section{Two Opposing Theories and New Approaches}

\subsection{Theories of Heterogeneity}

Regardless of the difference between the driving forces, many studies on strategic management have developed and used the concept of competitive advantage to explain a firm's competitiveness [2,4]. At the core of this central theme is the idea of strategic heterogeneity-a precondition to achieving competitive advantage. Put differently, competitive advantage presumes heterogeneity by its nature [19], an oft-argued position in mainstream academia. Scholars, focusing on IO, RBV, and competitive dynamics, have proposed that a firm strategically different from others in the same industry can outperform its peers. According to the IO theory, firms must identify and secure a unique position by analyzing the industry structure [2]. A unique position would enable a firm to earn higher profits, as the firm faces less competition, and perhaps, may even become a local monopoly [20,21]. Scholars who have studied the RBV do not wholly deny this proposition, and in fact, maintain "position theory" by complementing its weakness: internal perspective. Firms must have resources that are rare, valuable, non-substitutable, and inimitable to achieve and maintain this unique position [4]. Strategic heterogeneity arises from the acquisition and deployment of scarce, finite and valuable resources [22,23]. Competitive advantage may arise from core competencies [24]. Research on competitive dynamics has also indicated that, once a successful firm identifies and exploits market opportunities from its distinct position, it can take advantage of its first-mover status to build barriers to entry and imitation $[25,26]$. Successful firms must reestablish distinct positions that exploit new niches to stay ahead of the competition [27]. Although different from what formulates strategic heterogeneity and competitive advantages, the IO theory, the RBV, and theories in competitive dynamics all speak with one voice-strategic heterogeneity stakes out the competition and enables firms to earn higher rents.

\subsection{Theories of Homogeneity}

The practitioners' dilemma started, if not deepened, with the rise of research to conceptualize a firm's strategy according to the distance from the central tendencies of the industry [28-30]. Finkelstein and Hambrick [31] called this tendency strategic conformity. They argued that firms conforming to dominant practices should, on average, realize positive returns [30]. The observations that support this argument empirically have been found in previous research, such as studies in the US pharmaceutical industry [32], airline industries [28], and color television industry [33]. From these studies, it was found there were similarities in strategic activities among successful firms, which were different from failed firms. This implies that firms in the same industry consciously imitate each other. The rationale behind this argument is that high conformity increases legitimacy, which, in turn, improves performance [6,7].

Legitimacy can be defined inclusively as a "generalized perception or assumption that the actions of a firm are desirable, proper, or appropriate within some socially constructed system of norms, values, beliefs, and definitions" [34]. According to institutional and resource dependence theories, firms with high legitimacy are advantageous for two reasons: (1) external constituencies' confidence in the possibility of success [35], and (2) reduction of uncertainty [6]. Both lead to better access to resources and favorable contracts. The concept that best accounts for the process of building the homogeneity is isomorphism. There are two acknowledged isomorphism processes. Competitive isomorphism adopts market selection, wherein the market selects firms that possess the prerequisite elements for survival and vice versa [36]. Through this market process, similar types of firms survive, resulting in the appearance of homogeneity. The literature also introduced the concept of institutional isomorphism. Institutional isomorphism processes have been studied by many scholars [37-39] who categorized them according to their sources of isomorphism: coercive isomorphism (proceeded by the 
forces from government, suppliers, and powerful customers), mimetic isomorphism (practices from benchmarking, employee transfer, and consultants input), and normative isomorphism (sources from professional networks and education). Although different regarding what sources formulate strategic conformity, all agree that firms conforming to prevailing practices should, on average, accrue positive returns by acquiring greater legitimacy by key constituencies [30].

\subsection{New Approaches}

Somewhat polarized in the pursuit of either heterogeneity or homogeneity, the literature on strategic management and institutional theory has faced difficulties in integration, in spite of the needs and opportunities in real-world observations. This was still the case until the new institutional theory shifted its focus toward institutional sources and the dynamics of heterogeneity [17].

Scholars studying contemporary institutional theory have argued that firms need to achieve "optimal distinctiveness" to reconcile two competing pressures $[40,41]$. The core argument of optimal distinctiveness is that a firm's competitive advantage can be realized by both its firm-specific resource capital (assets and capabilities) and stock of institutional capital [16]. The optimal distinctiveness can be described as follows-it is the "balanced strategies and actions" that firms design and act on to reduce the tension of competing pressures and to maximize the profits that will be determined by the acceptance of stakeholders outside firms. Thus, legitimacy is still important. The legitimacy previously built by the focal firm in the isomorphism processes can be converted into firm-level institutional capital to enhance differentiation and increase the acceptance of firms' differentiation by external stakeholders [42,43]. This argument is currently more appealing, as competition occurs in multi-markets, and thus, the competing pressures increase because of the dynamic characteristics of the industry. In this case, the relative strength of conformity and differentiation pressures changes across time and space $[44,45]$.

Research in line with the ideas of optimal distinctiveness seems to be increasing. For instance, Deephouse [7] representatively attempted to investigate the relative impact of conformity and differentiation on a firm's financial outcome. The author concluded that moderately positioned firms face reduced competition for resources while maintaining legitimacy, which leads them to have a competitive advantage at some point in time. That is, firms with high conformity (beyond a certain point) can face competition that is more costly than the benefit of the legitimacy, while firms with low conformity can face a legitimacy challenge that is more costly than the benefit of reduced competition. Although seen as a counter-thesis against famous arguments of disadvantageously being "stuck-in-the-middle," it must be interpreted as an advantage of being "optimally-positioned." Following this perspective, some scholars have applied this idea of balance to various contexts in order to explain a firm's outcomes [46,47]. Some of these outcomes include alliance stability, financial outcomes, and corporate stock value. More recently, scholars have emphasized the effects of various combinations of different strategies on the stakeholder's perceptions and firms' outcomes [48,49].

\section{Hypotheses Development}

\subsection{Strategic Conformity for the Performance of Korean Firms}

Earlier, we mentioned the driving forces of homogeneity and heterogeneity. As a rationale for homogeneity that leads to conformity to a dominant norm in the industry, the institutional theory suggests an isomorphism process, where the sources are coercive, mimetic, and normative. Conversely, scholars of strategic management have argued that industry structure, firm-specific resources, and capabilities lead to heterogeneity. Even though the conformity level is widely different across countries and industries, the manufacturing industry as a whole in Korea seems to reflect the characteristics of the homogeneity that has developed over more than half the century.

Korea had started re-building its economy in the 1960s from the literal debris of the Inter-Korean War. It has achieved unprecedented economic growth in the past 60 years. Now, Korea positions itself 
as an economy with the 11th biggest gross domestic product worldwide and is set to reach $\$ 30,000$ in gross national income. This performance was led by government initiatives and industrial policies [50], especially by the government focusing its policies on various industries periodically. These include currency policies, tax incentives, and export credits at concessional interest rates for the light industry during the 1960s. In the 1970s and early 1980s, capital-intensive industries were supported under the Promotion Act by industries. Although the government supported many industries in the late 1980s, the knowledge-intensive and new technology-oriented industries have become the primary considerations since the late $90 \mathrm{~s}$.

Moreover, it was mainly government policies that supported technology transfers to firms, including the learning process of imported technologies and knowledge in the earlier periods of industry development [51]. In some industries, high protective barriers for infant industries were established, and few firms were granted monopolistic positions. The conglomerates these days established their ecological systems and led the nation's economy. Then, forward and backward linkages from these core firms were developed. Today, the status of many industries is due, in part, to the strong influence of core firms.

With this process having been developed and conducted, the condition that firms were inclined to adopt the industry recipe was established. Based on institutions and norms set by the government and society, firms in those industries were more likely to discover opportunities within the institutions for their own sake. Instead of taking bold steps to establish new ways of doing business, firms in those times were more preoccupied with emulating advanced economies in almost every business aspect. The success factors must have been geared toward "whether to get into the value chains of major streams". We can reasonably infer that government-led policies worked as a force of coercive isomorphism, as we have seen in the case of the Korean manufacturing industry.

Isomorphism arises in various forms. Mimetic and normative isomorphism played an essential role for firms in Korea to become alike. Oligopolistic structures of industry boosted competition and cooperation in the areas of new technologies and skills through benchmarking among big players. Conversely, other industry players that had business ties with such big firms also made their way into the value chains by systemically aligning the business system with its leaders. Export-oriented strategies also strengthened the condition of the isomorphic process. The fast catching-up capabilities of Korean firms built relative advantages for them over other global competitors. This expanded their business map to other continents and regions. Successful factors for global strategy were learned and adopted interchangeably among many players in the industry system.

We must note that there was considerable effort to be heterogeneous by individual firms in various industries, such as consumer products, chemicals, and IT hardware. However, the overall impact of this effort must not have lasted long owing to strong and effective mimetic practices, as well as the challenges from the stakeholders familiar with the existing systems. Rapid industrial growth would generally encourage firms to ride the wave on proved paths, rather than creating new waves. Particularly, developing countries, partners, and overseas customers would prefer legitimacy over uniqueness.

Thus, to ascertain whether homogeneous or heterogeneous factors are more relevant to explain the performance of Korean manufacturing firms, we can infer that firms must have first achieved critical conditions. Firms in the industry that are highly influenced by government policy and dominant industry players, such as conglomerates, would do better when they pay close attention to and conform to the industry norms and standards. Accordingly, we develop the hypothesis below.

Hypothesis 1 (H1): For firms in manufacturing industries in Korea, the strategic conformity will have a positive relationship with the firm's performance. 


\subsection{Strategic Conformity and Innovation for the Performance of Korean Firms}

In the last several decades, manufacturing firms in Korea have built competitive advantages by conforming to industry norms. However, due to the emergence of a knowledge-based society since the late 1990s, strategies seeking similar success factors were found to be insufficient to guarantee sustainable growth. Governments, as well, emphasized R\&D and innovations, resulting in the establishment of industry clusters across the nation. These industry clusters acted as hubs of innovation, having developed various alliances between large firms, SMEs, and universities. The major role of R\&D and innovation began to shift from the government to private firms from the mid-1980s [52]. The share of R\&D from the private sector increased sharply from $30 \%$ in the late 1970 s to $75 \%$ in 2011. New technologies developed and adopted in many industries, such as the Internet of Things, biotechnologies, and artificial intelligence, accelerated wide and deep innovations in mature manufacturing industries. Unlike firms in the early developmental stage during the earlier stages of economic development in Korea, firms had to develop competency and competitiveness for differentiation throughout the 1990s and early 21 st centuries. According to notions and theories such as strategy design and optimal distinctiveness, the efforts that firms made for innovation with conformity interacted, seem to have brought different results in terms of firm performance.

Manufacturing firms in Korea must choose the level and the scope of innovations no matter what level of conformity they are in. The rule of thumb is to determine how to maximize the outcome based on balancing the choice of strategic conformity and innovative activities. From the perspective of strategy design, firms in a high level of conformity are more likely to face difficulty in increasing their performance by successfully implementing innovation due to their inertia. Instead, the low level of conformity will be beneficial for maximizing performance through organizational and structural flexibility [13-15]. Those firms might have a culture of creative learning and change, which can help them increase the level of performance by implementing innovation. Conversely, contemporary institutionalism suggests that competing forces that shape firms' strategy and business models make them both different and similar, which can be considered complementary by many stakeholders, and drive better performance $[7,16,17]$. We, following the optimal distinctiveness theory, believe that competitiveness could possibly be maintained through similarities in some aspects, and differences in other aspects.

A Science \& Technology Policy Institute (STEPI) survey [53] showed that Korean firms have not abandoned their high-level conformity strategies as a basis of management policy, even during the innovation-driven era. As a matter of fact, manufacturing firms in Korea are still concentrated in an area with a relatively small distance from the average. The data from the same study revealed that $63.9 \%$ of the surveyed companies have relatively high conformity. Although some have done better than others, they created a virtuous cycle as members of the homogeneous groups. However, as the knowledge-based society has emerged, and the convergence of technologies have become ripe for realization in the new business model, a considerable number of firms have adopted the new dynamics of competitive advantages. We believe that more successful firms among firms that have maintained competitive advantages would be the ones that exploit their legitimacy as a stock of capital. Once perceived as legitimate by various stakeholders, such as customers, governments, professionals, and other institutions, their innovation initiatives would receive support in the form of resources and capabilities [54].

The market itself speeds up its adaptability to the newness, and tremendous expectation is required even of these firms. In a nutshell, firms can be successful by taking alternative paths, while they configure their unique combinations of resources $[17,42]$. As firms face multiple competitions across the blurred industry domains and struggle to manage a rapid change of environments with multiple interest parties, they are evaluated on multiple strategic dimensions. This situation requires firms to be flexible to build competitive advantages. Firms would have to understand the external requirements to balance legitimacy and difference in their business activities and value propositions. For firms that implement this balanced strategy in a well-configured manner, if one dimension is deviant from the 
industry norms resulting in legitimacy challenges, the other dimension can act as a compensatory force [17]. Some scholars have suggested this relationship between customer service and products [55], and others with the governance system [28]. Successful Korean firms have adopted new capabilities and business models in accordance with the more complex environments and must have exploited their legitimacy as a stock of capital.

In sum, legitimacy as a stock of capital and innovation efforts as a new source of sustainable advantages can be mutually leveraged. Korean firms in the manufacturing industry, we believe, are good examples of this argument. The overarching strategic movement of Korean firms is that they sought two seemingly competing strategies together. This is beyond the extant research focused on optimal distinctiveness between functional strategies or activities. We argue that firms' decision to set the conformity position and to conduct innovation require more integrated and fine-tuned management capabilities since configuring these two strategies has a broader and deeper impact on the business than dealing with specific functional strategies or activities. Their higher conformity acts as the driver of continuous innovation activities when they need to be different. This is, we argue, the status of the optimal distinctiveness. Accordingly, we develop the hypothesis below.

Hypothesis 2 (H2): For firms in the manufacturing industry in Korea, the higher level of radical innovation will strengthen the positive relationship between conformity and firm performance.

\subsection{Moderating Effect of Industry Dynamism}

Although the interest of this study is mainly the manufacturing industry in Korea as a whole, it might not be appropriate to assume and generalize that all industries have the same contextual surroundings. The resource dependence theory classifies the industry context into three sets: munificence, dynamism, and complexity [56]. Munificence can be defined as the abundance of external resources and opportunities that can help a firm's growth [56-58]. Dynamism refers to the volatility of the changes in an industry, which increases the uncertainty of a firm's predictions $[56,59]$. Finally, complexity refers to the degree of concentration and heterogeneity $[57,59,60]$. Among these attributes, dynamism most likely changes the effects of optimal distinctiveness of strategic conformity with innovation on a firm's performance [56,57]. It arises from the potential change of regulation and other features, such as new laws and acts, changes in the global ecosystem for production, new-to-the-world products, an innovative substitution, and breakthrough skills and technologies in the market [61]. These factors, as some scholars have mentioned [62], can accelerate market volatility.

Scholars have argued that, when an industry grows in dynamism, it requires differentiation that challenges the existing rules of competition [63]. Increasing dynamism might provide the conditions for firms with high level of innovation-and thus, successfully differentiated-to outperform others in the industry [64]. From the perspective of institutional theory, however, the uncertainty caused by the dynamic situation makes it more challenging to meet stakeholders' needs. Firm managers would be less discretionary and indecisive when mitigating the effects [65]. In this circumstance, it is unrealistic to assume that the legitimacy previously built by firms in the isomorphism processes sufficiently converted into firm-level institutional capital to increase the acceptance of firms' differentiation by external stakeholders [42,43]. Therefore, it might be more realistic to assume that, before initiating any changes, most firms would tend to wait until a sign of plausible new success factors appears. The careless efforts of firms would even lead them to the status of being "stuck-in-the-middle" as opposed to the state of being "optimally distinctive".

According to Korea Investors Service, Inc., a financial advisory service in Korea, the shipbuilding industry is an example that is at the highest position based on the industry volatility evaluation. It is characterized as global, hyper-competitive, and dependent on the economy of the front industry, which includes logistics and export-oriented industries. Many Korean shipping-building firms have failed to leverage their legitimacy as a stock of capital for innovation. On the opposite side of the 
evaluation of volatility analyzed by the same financial advisory service is the food and beverage industry. Unlike the shipbuilding industry, the dynamism level in this industry is low. Thus, it would have a lesser negative effect on a firm's efforts to be optimally distinctive by balancing conformity and innovation.

Consequently, we believe that there must be meaningful variances in firm performance, based on the level of industry dynamism, when the effects of conformity to supplement innovation, or vice versa, are taken into consideration. Based on extant literature [61,65], we expect the moderating effect of industry dynamism on the optimal distinctiveness of strategic conformity with innovation to be as follows.

Hypothesis 3 (H3): For firms in manufacturing industries in Korea, the industry dynamism will have a negative impact on the effect of optimal distinctiveness of conformity with innovation in performance.

\section{Research Methods}

\subsection{Sample}

The initial sample of this study was the manufacturing firms included in the Korea Innovation Survey 2014 (KIS 2014) [53] conducted by STEPI (Science and Technology Policy Institute). KIS 2014 provides detailed information about the trends in firms' innovation activities in the Korean manufacturing and service industries. Especially, after the 2009 global financial crisis intensified the uncertainty of business environment, which made Korean firms try more eagerly to find new competitive advantage by either conforming to the industry norm or conducting innovation. We believe that the data from 2011 to 2013 used for this study can highlight strategic behavior of firms.

To conduct the analysis, we designed the proper data set for this study. First, some of the cases were excluded, as the measures for independent and dependent variables, mainly conformity and return on investment (ROI), were not provided by the data providers. The exclusion reduced the sample data set to 2831 from 4075. Then, the companies that participated in any radical innovation activities between 2011 and 2013 were selected. The final data set size was 448 .

\subsection{Variables and Measures}

\subsubsection{Dependent Variables}

The variable used to examine the impact of strategic conformity and/or innovation on firm performance is the financial profitability ratio [16,30,66]. Although some studies used other economic measures, such as revenue growth ratio, market share ratio, and others, we believe that the profitability ratios are the most appropriate, as they show the net impact of firms' operations, including the effect of innovation on firm performance. Thus, we used averaged ROI from 2013 to 2015 to take the time gap between the leading (conformity) and the lagging indicators ( $\mathrm{ROI}$ and investment in innovation) into consideration. The data were collected from "DART," a financial data and information providing platform operated by the Financial Supervisory Service of Korea.

\subsubsection{Independent Variables}

Strategic conformity (Main effect): Strategic conformity refers to how close firms' strategic profile is to the central tendency of the industry. We adopted a method of measuring firm-level strategic conformity developed and validated by Finkelstein and Hambrick [31], and used by other scholars as well $[67,68]$. The measures that have been previously used by many scholars have six dimensions of business key functional activities [16,31]. These strategic dimensions include advertising intensity (advertising expense/sales), capital intensity (fixed assets/number of employees), plant and equipment newness (net plant and equipment/gross plant and equipment), R\&D intensity (R\&D expense/sales), 
overhead efficiency (selling, general, and administrative expense/sales), and financial leverage (total debt/equity).

As the capital intensity comes out as a numeric value that is different from other measures shown as a ratio, we converted all to the standardized value and summed them to obtain each firm's strategic profile as a numeric value. The level of conformity of each firm was calculated by subtracting the numeric value of the strategic profile from the average. As the subtracted value from the average has the same distance, the negative values were transformed to the absolute value. Thus, the higher value represented lower conformity and vice versa, making the analysis confusing. This reverse effect was solved by subtracting each value again from the highest value, resulting in a higher conformity level with a higher value. Again, by definition, the strategic conformity becomes higher when it centers around the average, and lower when it deviates from the average. The measure, ZCNFMTY, reflects the theoretical concept and solves the reverse effect. To collect and operationalize the variables, we collected data from the "KIS Value", a credible financial data providing system run by NICE Corp. of Korea.

Firm Innovation and Industry Dynamism (Moderating effect): This study considered firms' innovation as the moderating variable. As we discussed in the introduction part, the innovation has strategic importance. Among the measures used in prior studies, we measured firms' innovation using the numeric value of investment for radical innovation (ZINNO). Here, radical innovation is defined as the activities that produce totally different or much improved outputs from the existing ones in four categories: product, process, marketing, and organization. This data was gathered from the KIS 2014, where its model is based on the Oslo innovation manual developed by OECD. The investment value of innovation summed up all the radical innovation activities related to the four categories. As for the interaction variables, to examine the moderating effects we used measures such as ZCNFMTY X ZINNOLN.

For the industry dynamism, we built our construct based on the model used widely by many scholars $[69,70]$. The data were collected from "DART", the same platform where we gathered dependent variables. We first aggregated the industry sales data over five years, from 2009 to 2013. As previous industry volatility can influence firms' conformity and innovation, we incorporated industry data of 2009 and 2010 under the assumption that industry volatility during these periods would impact strategic conformity and innovation results in 2011. We then regressed this sales value against time to obtain the coefficient. Industry dynamism, named ZINDYNA, was measured by the standard error of this regression slope coefficient. For the interaction variables to examine the 3-way results, we used a measure as such ZCNFMTY X ZINNOLN X ZINDYNA.

\subsubsection{Control Variables}

The financial outcomes of firms can be affected by various factors. We controlled the effects of those variables using data collected from the KIS 2014 survey. First, firms that have been around in the industry for a longer time than others would be better positioned to outperform competitors. Thus, we considered this variable by creating the measure, COAGE.

Second, from the perspective of the affordability of implementing strategies, large firms are more likely to be active in strategic portfolio management [71-73]. Following this logic and the approaches of prior research, we controlled the variable of corporate size (COSIZE) by measuring the number of employees.

Third, revenue determined as the natural logarithm (REVLN) and revenue growth (REVGROWTH) were taken into consideration. Both variables are meaningful for managers to decide on the investment size and the timing. A higher average of revenue for a certain period with an increasing growth rate would make the new investment more affordable for firms.

Fourth, we created dummy variables to control the impact of the stock exchange practice in the open market (STOCKMKT_DUM). Those firms that trade their stocks in the market are more likely to be monitored and screened for profitability by shareholders. They have long-term investments for growth 
and are more likely to be dependent with respect to various considerations. Finally, we controlled the number of R\&D personnel after returning the numeric value to the natural logarithm, (R\&DEMPLN).

\section{Results}

\subsection{Research Model}

This study was conducted to ascertain the impact of strategic conformity on firm performance. In addition, it also ascertains the role and impact of innovation in the relationship with conformity on performance. Finally, we examine the role of industry dynamism as a specific context, which moderates the effects of strategic conformity and innovation on firm performance. The research model is presented in Figure 1 below.

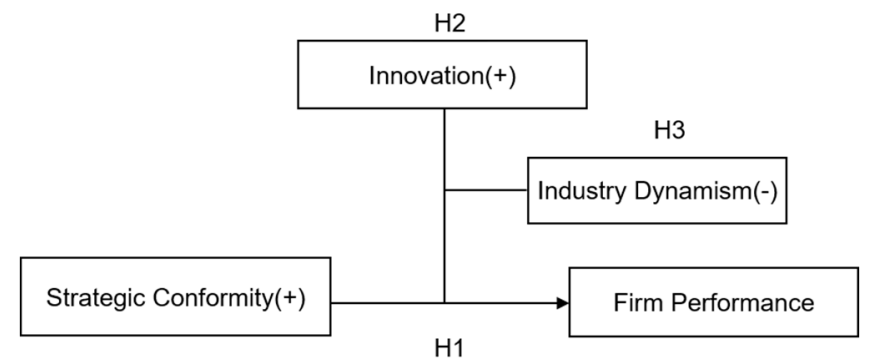

Figure 1. Research model.

\subsection{Statistical Results and Interpretation}

Table 1 shows the correlation between the variables. The result shows the multicollinearity problem must not be the case for further analysis.

Table 1. Descriptive statistics and correlation matrix $(\mathrm{N}=448)$.

\begin{tabular}{|c|c|c|c|c|c|c|c|c|c|c|}
\hline & 1 & 2 & 3 & 4 & 5 & 6 & 7 & 8 & 9 & 10 \\
\hline 1. ROI & 1.000 & & & & & & & & & \\
\hline 2. COAGE & 0.032 & 1.000 & & & & & & & & \\
\hline 3. COSIZE & 0.007 & $0.342^{* * *}$ & 1.000 & & & & & & & \\
\hline 4. REVLN & $0.094 *$ & $0.343^{* * *}$ & $0.632 * * *$ & 1.000 & & & & & & \\
\hline 5. REVGROWTH & $0.173^{* * *}$ & -0.072 & -0.025 & 0.039 & 1.000 & & & & & \\
\hline 6. STOCKMKT_DUM & $-0.152 * *$ & $0.219^{* * *}$ & $0.386^{* * *}$ & $0.404^{* * *}$ & -0.013 & 1.000 & & & & \\
\hline 7. R\&DEMPLN & 0.052 & $-0.196^{* * *}$ & $-0.147^{* *}$ & -0.071 & -0.053 & $\begin{array}{l}0.144 \\
* *\end{array}$ & 1.000 & & & \\
\hline 8. ZCFMTY & $0.208^{* * *}$ & $-0.102 *$ & -0.066 & -0.034 & $-0.088 *$ & -0.057 & -0.036 & 1.000 & & \\
\hline 9. ZINNOLN & 0.023 & $0.164^{* * *}$ & $0.493^{* * *}$ & $-0.489^{* * *}$ & -0.025 & $\begin{array}{l}0.366 \\
* * *\end{array}$ & $0.254^{* * *}$ & $-0.111 * *$ & 1.000 & \\
\hline 10. ZINDYNA & 0.050 & -0.030 & -0.083 & $-0.129 * *$ & -0.035 & 0.030 & $0.181^{* *}$ & 0.068 & 0.024 & 1.000 \\
\hline
\end{tabular}

Table 2 summarizes the results of the multiple hierarchical regressions.

Model 2, shown in Table 2, describes the analysis to examine the impact of firms' conformity on its financial performance. According to the result, -1.313 of $\beta$ with the $p$-value $(0.000)$ - the conformity of the manufacturing firms in Korea has a significant positive impact on their performance. This finding implies that firms under strong isomorphism pressures, such as government policy and the influence of big players, would have better performance by positioning themselves close enough to the industry standard and norm. Thus, $\mathrm{H} 1$ is supported. 
Table 2. Multiple Hierarchical Regression for Return on Investment.

\begin{tabular}{|c|c|c|c|c|c|}
\hline \multirow{2}{*}{ Step } & \multirow{2}{*}{ Variables } & Model 1 & Model 2 & Model 3 & Model 4 \\
\hline & & B & B & B & B \\
\hline \multirow{8}{*}{1} & ControlVariables & & & & \\
\hline & COAGE & 0.022 & 0.029 & 0.024 & 0.021 \\
\hline & COSIZE & $-5.374 *$ & $-5.043 *$ & $-4.821 *$ & -4.535 \\
\hline & REVLN & $1.449 * * *$ & $1.353^{* * *}$ & $1.294^{* * *}$ & $1.306^{* * *}$ \\
\hline & REVGROWTH & $2.114^{* * *}$ & $2.436^{* * *}$ & $2.524^{* * *}$ & $2.483^{* * *}$ \\
\hline & STOCKMKT_DUM & $-2.397^{* * *}$ & $-2.422 * * *$ & $-2.495^{* * *}$ & $-2.505^{* * *}$ \\
\hline & R\&DEMPLN & 0.577 * & 0.546 & 0.546 & 0.530 \\
\hline & MainEffectVariables & & & & \\
\hline \multirow{4}{*}{2} & ZCNFMTY & & $1.313^{* * *}$ & 0.448 & 0.644 \\
\hline & ZINNOLN & & 0.182 & 0.205 & 0.227 \\
\hline & ZINDYNA & & 0.236 & 0.085 & 0.079 \\
\hline & Interaction & & & & \\
\hline \multirow{3}{*}{3} & ZCNFMTYXZINNOLN & & & $1.058^{* * *}$ & $0.667 *$ \\
\hline & ZCNFMTYXZINDYNA & & & 0.432 & $1.307^{* *}$ \\
\hline & ZINNOLNXZINDYNA & & & 0.178 & 0.177 \\
\hline \multirow{8}{*}{4} & Three-wayinteraction & & & & \\
\hline & ZCNFMTYXZINNOLNX & & & & \\
\hline & ZINDYNA & & & & $-1.370^{* *}$ \\
\hline & Model & & & & \\
\hline & $F$-Statistics & $8.503^{* * *}$ & $9.155^{* * *}$ & $5.084^{* *}$ & $12.023^{* *}$ \\
\hline & $\mathrm{R}^{2}$ & 0.104 & 0.157 & 0.185 & 0.207 \\
\hline & AdjustedR $^{2}$ & 0.091 & 0.139 & 0.163 & 0.183 \\
\hline & Changesin $^{2}$ & & 0.053 & 0.029 & 0.022 \\
\hline
\end{tabular}

$* p<0.05 ; * * p<0.01 ; * * *<0.001$. Variables are denoted as such ROI: Return on investment, COAGE: Corporate age, COSIZE: Number of employees, REVLN: Sales, REVGROWTH: Average growth rate in sales, STOCKMKT_DUM: Firms' stock-trade in the stock market or not, R\&DEMPLN: Number of R\&D personnel, ZCNFMTY: Conformity level, ZINNOLN: Investment size in innovation, ZINDYNA: Industry dynamism level.

We can infer that the homogeneity of Korean firms in the manufacturing industry would increase the legitimacy of a firm in the eyes of influential stakeholders in order to be accepted as a legitimate member. High legitimacy, in turn, would increase accessibility to valuable resources and market opportunities to realize high profitability. Throughout the legitimacy building process, a firm might be able to build a stock of institutional capital to use in various fields and with various stakeholders even though the direction, size, sources, and content of isomorphic pressures change. On the other hand, the innovation of Korean firms has no significant impact on their performance independently.

In Model 3 shown in Table 2, the moderating effect of innovation on the relationship between conformity and performance of firms is examined in the variable ZCNFMTY X ZINNOLN. The result- 1.058 of $B$ with a $p$-value $(0.000)$ reveals that $\mathrm{H} 2$ is strongly supported. It shows that firms with high legitimacy could do innovation as a compensatory force to increase their performance. The stock of institutional capital developed by the isomorphism process would make it possible for these firms to capture opportunities and resources from various stakeholders. Radical innovation requires both external and internal conditions. It requires support from many stakeholders, from investors, suppliers, and customers such as innovators and early adopters, to competitors that could also form the new market. These stakeholders either choose to support or disregard firms' innovation.

Strong legitimacy would provide these stakeholders with the high expectancy and validity they require. Internally, mimetic and normative isomorphism processes could enable firms to build capabilities that would help them exploit adapted knowledge and skills in order to explore new opportunities in their way. They would follow not only the practice but also the logic of the innovation. In our study, successful Korean firms are likely to leverage the stock of capital for adoption by stakeholders and successful innovation. The graphic presentation of the conditional effect of strategic conformity and performance in three different levels of innovation (high $=1.39$, middle $=0.50$, low $=-0.40$ ) is shown in Figure 2. It presents that the positive relationship between strategic conformity and performance is most strongly intensified when the level of firm innovation is high. 


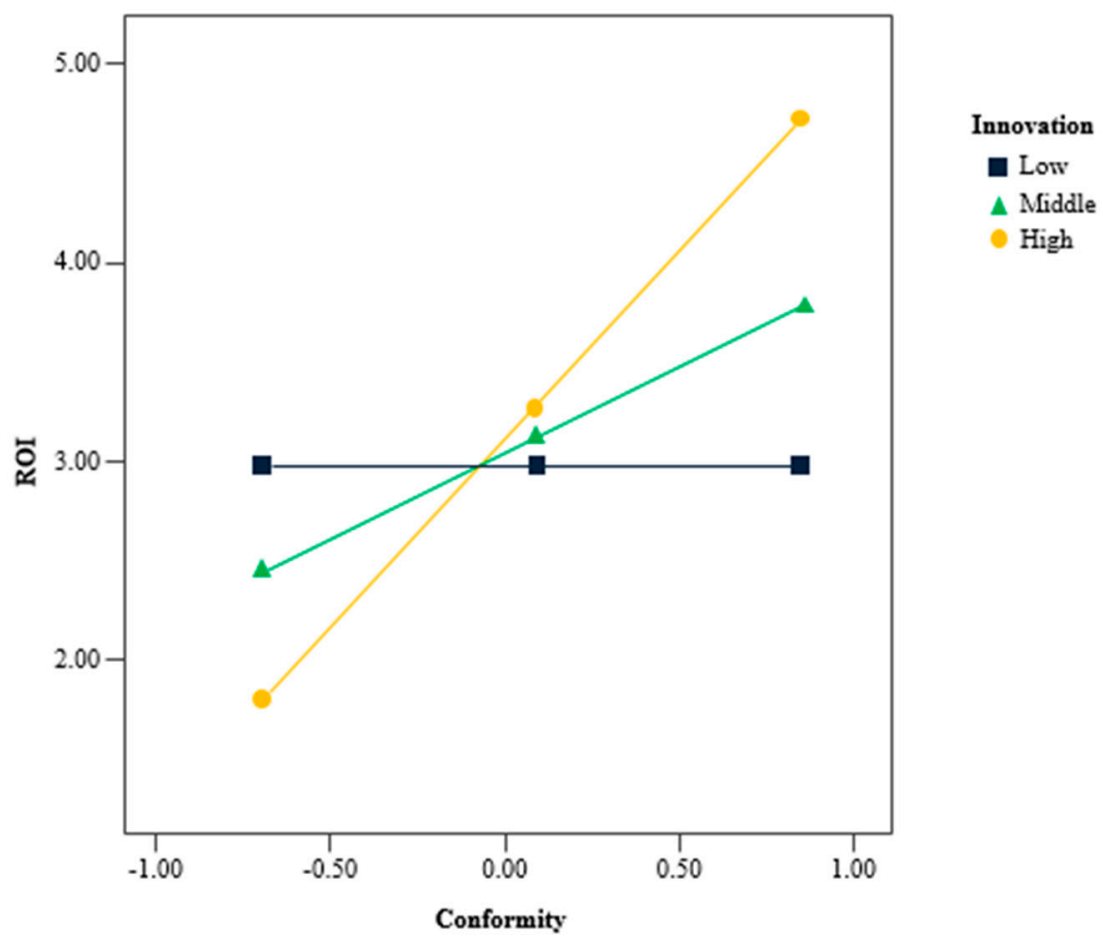

Figure 2. Conditional effect of strategic conformity and performance at three different levels of innovation interaction.

H3 posits that the interaction effects of conformity (ZCNFMTY) and innovation (ZINNOLN) on performance (ROI) vary depending on the level of the additional moderating variable, industry dynamism (ZINDYNA). Model 4 in Table 2 shows this relationship. With -1.370 of $\beta$ with the $p$-value (0.01), H3 is also supported. Interestingly, the result indicates that the negative effect of industry dynamism is valid under the circumstances wherein strategic conformity and innovation are both involved. This finding suggests that a synergistic or a compensatory relationship between strategic conformity and innovation would not occur in a highly dynamic environment.

Figure 3 is a graphic presentation of this three-way interaction effect on the performance of sample firms. We can see the general tendency of a decrease in the gap of the conditional effects of strategic conformity and innovation on the performance of firms when the dynamism increases (from the top panel to the bottom panel). The interaction effect is high when the dynamism is low $(-0.68)$ whereas the interaction effect is low when the dynamism is high (4.47).

To further present how the interaction effect between conformity and innovation on performance depends on the level of industry dynamism, we identified regions of significance for interaction effects across the entire range of the moderator by employing the Johnson-Neyman technique [74] using PROCESS Macro [75]. According to the findings in this analysis (Table 3), the interaction effects of strategic conformity and innovation in the performance of sample firms are statistically significant when the level of dynamism is at $W \leq 0.032$ and $W \geq 1.673$. The results also show that the interaction effect of conformity and innovation is highest at the lowest value of dynamism $(\mathrm{W}=-0.676)$, decreases as the value of dynamism increases, and finally shows a negative effect from the value of dynamism at 0.612 (See Table 3). 

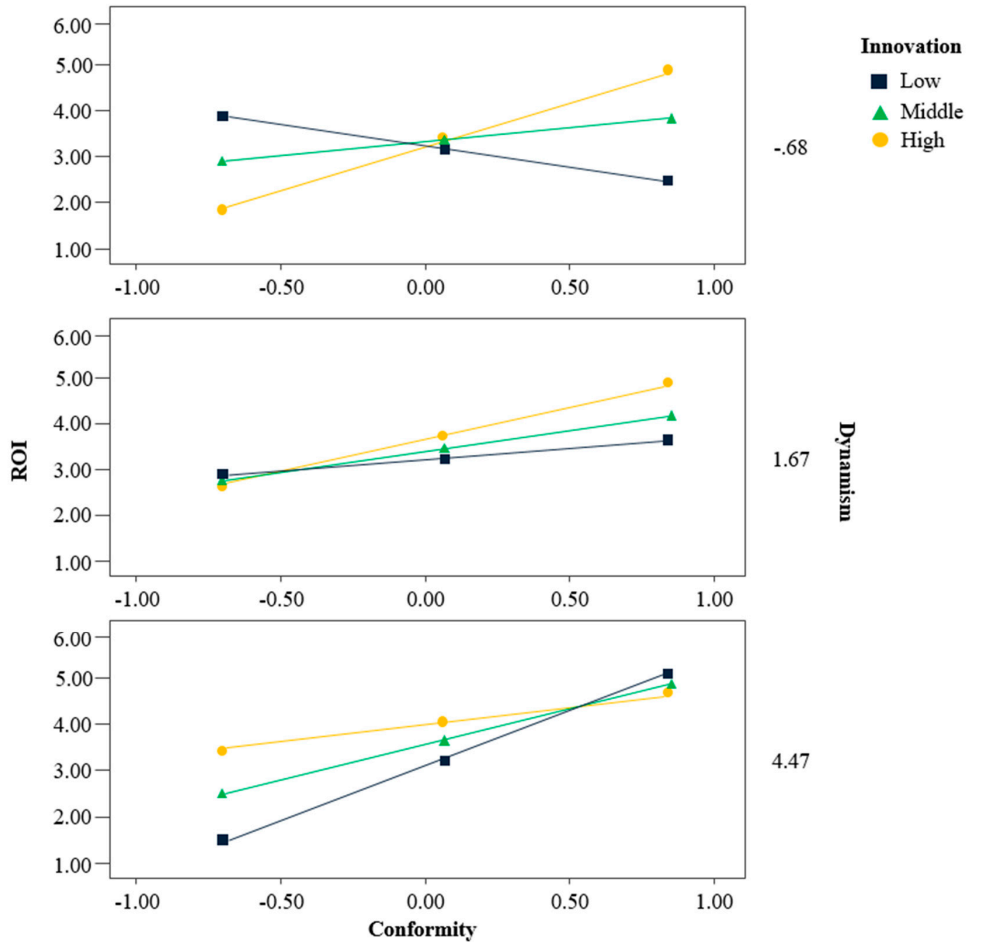

Figure 3. Three-way interaction effects; Conditional effects of strategic conformity and innovation on the performance of firms at three different levels of dynamism.

Table 3. Moderating Effect based on Johnson-Neyman Technique.

\begin{tabular}{|c|c|c|c|c|c|c|}
\hline \multicolumn{7}{|c|}{ Moderator Value(s) Defining Johnson-Neyman Significance Region(s) } \\
\hline \multicolumn{3}{|c|}{ Value } & \multicolumn{2}{|c|}{$\%$ Below } & \multicolumn{2}{|c|}{$\%$ Above } \\
\hline \multicolumn{3}{|c|}{0.032} & \multicolumn{2}{|c|}{68.973} & \multicolumn{2}{|c|}{31.027} \\
\hline \multicolumn{3}{|c|}{1.673} & \multicolumn{2}{|c|}{94.420} & \multicolumn{2}{|c|}{5.580} \\
\hline \multicolumn{7}{|c|}{ Conditional effect of $\mathrm{X} \times \mathrm{M}$ on $\mathrm{Y}$ at values of the moderator $(\mathrm{W})$} \\
\hline $\mathbf{W}$ & Effect & se & $\mathbf{t}$ & $p$ & LLCI & ULCI \\
\hline-0.676 & 1.593 & 0.330 & 4.829 & 0.000 & 0.945 & 2.242 \\
\hline-0.418 & 1.240 & 0.296 & 4.186 & 0.000 & 0.658 & 1.823 \\
\hline-0.161 & 0.887 & 0.296 & 3.001 & 0.003 & 0.306 & 1.468 \\
\hline 0.032 & 0.624 & 0.317 & 1.965 & 0.050 & 0.000 & 1.247 \\
\hline 0.097 & 0.534 & 0.328 & 1.627 & 0.105 & -0.111 & 1.179 \\
\hline 0.355 & 0.181 & 0.386 & 0.469 & 0.639 & -0.578 & 0.940 \\
\hline 0.612 & -0.172 & 0.459 & -0.375 & 0.708 & -1.075 & 0.730 \\
\hline 0.870 & -0.525 & 0.542 & -0.969 & 0.333 & -1.590 & 0.539 \\
\hline 1.128 & -0.878 & 0.630 & -1.394 & 0.164 & -2.116 & 0.360 \\
\hline 1.385 & -1.231 & 0.722 & -1.706 & 0.089 & -2.650 & 0.187 \\
\hline 1.643 & -1.584 & 0.816 & -1.942 & 0.053 & -3.188 & 0.019 \\
\hline 1.673 & -1.625 & 0.827 & -1.965 & 0.050 & -3.250 & 0.000 \\
\hline 1.900 & -1.938 & 0.912 & -2.125 & 0.034 & -3.730 & -0.146 \\
\hline 2.158 & -2.291 & 1.009 & -2.271 & 0.024 & -4.273 & -0.308 \\
\hline 2.416 & -2.644 & 1.107 & -2.389 & 0.017 & -4.819 & -0.469 \\
\hline 2.673 & -2.977 & 1.205 & -2.487 & 0.013 & -5.366 & -0.628 \\
\hline 2.931 & -3.350 & 1.304 & -2.569 & 0.011 & -5.913 & -0.787 \\
\hline 3.189 & -3.703 & 1.404 & -2.638 & 0.009 & -6.462 & -0.944 \\
\hline 3.446 & -4.056 & 1.503 & -2.698 & 0.007 & -7.011 & -1.101 \\
\hline 3.704 & -4.409 & 1.603 & -2.750 & 0.006 & -7.561 & -1.258 \\
\hline 3.962 & -4.762 & 1.704 & -2.795 & 0.005 & -8.111 & -1.414 \\
\hline 4.219 & -5.115 & 1.804 & -2.835 & 0.005 & -8.661 & -1.570 \\
\hline 4.477 & -5.468 & 1.905 & -2.871 & 0.004 & -9.212 & -1.725 \\
\hline
\end{tabular}

Variables are denoted as such X: ZCNFMTY, M: ZINNOLN, W: ZINDYNA. 
The result suggests that firms seeking optimal distinctiveness between strategic conformity and innovation will face more challenges during high uncertainty in the industry environment. As we develop the logic, optimal distinctiveness can be realized by appealing to various stakeholders at the same time by leveraging the legitimacy capital. When industry volatility increases, the information needed by the stakeholders to accept a firm's new approach would be greater than in a normal situation. The market would require more assurance on the value proposition of the latest products and services. Suppliers and other partners as well would be less willing to invest or join during higher uncertainty.

Moreover, firm managers would be less decisive with respect to losing the opportunity, or they would spend excessive effort and time on stakeholders only to miss the right timing. The Korean manufacturing industry has been exposed to a high degree of change recently. With fluctuations in the global economy, trends in the industrial revolution have caused confusion in the development of policies. As a matter of fact, government policy for industry innovation has been criticized by many experts for its ambiguity [52]. In a situation like this, the efforts toward optimal distinctiveness would create more cost than benefit.

\section{Discussion}

According to traditional theories in strategy, including IO, RBV, and competitive dynamics, firms must differentiate themselves from their competitors to obtain competitive advantages. The reality is that firms cannot be different in all dimensions and should not be same in all aspects. This reality indeed calls for new approach in the strategic management field: optimal distinctiveness. Our findings provide empirical evidence for this new approach in several ways. Theoretically, research has tended to discuss strategy as a single construct and has focused on a firm's strategy, evolution of it, and the substitution by another strategy [76]. Coexistence of strategies has not been explored much until recent research streams started recognizing the supplementary characteristics of multiple strategies [40]. Our findings reveal that two overarching strategies—conformity and innovation-coexist and drive better performance. They reveal that firms conform to the industry norm and at the same time try to differentiate themselves to achieve success; thus, two seemingly opposing forces can act as synergistic forces depending on the context. Our findings are consistent with those of open innovation literature suggesting that firms can pursue both contradictory strategies simultaneously without causing any conflicts or trade-offs by externalizing either one of them through strategic alliances [40], providing a new perspective for organizational ambidexterity.

Practically, this study shows that managing the seemingly opposing forces must be treated not as a dilemma but as an opportunity for sustainable growth. Therefore, managers in the firms need to shape their firms as somewhat homogeneous or heterogeneous, to various extents, according to various environmental conditions.

The research model of this study was tested based on the data of Korean firms. However, we believe that the findings can be applied to many other firms in different countries, especially in developing countries, where high isomorphic forces play an important role in economic development, and where innovation efforts and outputs have been increasing [77].

Although successful in testing the theories under the certain situation of Korea's manufacturing firms, this study is not immune to limitations. Considering the moderating effects of the industry environment on the relationship between strategic conformity and innovation, we still believe that industry dynamism is the most relevant and significant variable in the context of this study because dynamism, as a factor, makes stakeholders sensitive and managers indecisive. The Korean manufacturing industry is characteristically especially volatile to industry changes. The other two variables, munificence and complexity, are nevertheless the classical factors of industry context. Munificence is assumed to be reflected, to some extent, to firms' sales growth in our model. Therefore, adding this variable might entail more confusion than clarity, whereas the inclusion of complexity would probably produce a value-added result. 
Furthermore, we suggest prospective avenues for future research. First, strategic conformity and innovation can have different impacts on performance according to a firm's life cycle and industry life cycle. With the increased emergence of new ventures, we must identify how differently these ventures respond to the environment to shape optimal distinctiveness in comparison with incumbent players. Moreover, ventures in innovative industries and those in traditional industries may have different activities in shaping their optimal distinctiveness. Second, isomorphic processes can vary, as scholars have already suggested. According to industry characteristics, some forces can have more impact on firm performance when combined with specific innovations. By studying these factors, isomorphic forces, and innovation types, we can offer more concrete insights at the individual firm level and the industry level. Third, there must be internal activities and managerial discretion factors that can act as inputs to shape the level of strategic conformity and optimal distinctiveness. To tap into this area, we must push for an integrated understanding of the new theory. Finally, the type of optimal distinctiveness must be presented in the future. Optimal distinctiveness can be realized in many different combinations. Product and services, technology and business model, strategy, and operations are the areas that can be further studied.

\section{Conclusions}

In this paper, we built on and extended previous research on the conceptualization of optimal distinctiveness. Based on the sample of Korean manufacturing firms, we first hypothesized that, in an environment with strong isomorphic forces, firms would be driven by homogeneity to conform to industry norms and standards. The findings of this study support this hypothesis. Manufacturing firms in Korea that have been under pressure of homogeneity have built their competitive advantages through isomorphic processes. We further set up the second hypothesis on the manufacturing firms in Korea based on the theoretical argument in the previous research. The findings of the study showed that manufacturing firms in Korea with high strategic conformity performed better with radical innovation combined. Finally, we introduced industry dynamism into our model to see the conditional effects of optimal distinctiveness of strategic conformity with innovation on the performance of sample firms at the different levels of industry dynamism. As hypothesized, the findings show that industry dynamism decreases the positive interaction effects of strategic conformity and innovation on firm performance.

Author Contributions: Conceptualization: M.S.L. and J.W.Y.; methodology: M.S.L. and C.Y.K.; data collection: M.S.L. and C.Y.K.; Analysis: M.S.L. and C.Y.K.; validation: J.W.Y.; writing: M.S.L.; reviewing and editing: J.W.Y.; revision and resubmission process: M.S.L., C.Y.K. and J.W.Y.; supervision, J.W.Y. All authors have read and agreed to the published version of the manuscript.

Funding: This paper was supported by Konkuk University in 2019.

Conflicts of Interest: The authors declare no conflict of interest.

\section{References}

1. Perry, M.J. Fortune 500 firms 1995 vs. 2017: Only 60 Remain, Thanks to Creative Destruction that Fuels Economic Prosperity. 2017. Available online: http://www.aei.org/publication/fortune-500firms-1955-v-2017-only-12-remain-thanks-to-the-creative-destruction-that-fuels-economic-prosperity (accessed on 2 July 2020).

2. Porter, M.E. Industry Structure and Competitive Strategy: Keys to Profitability. Financ. Anal. J. 1980, 36, 30-41. [CrossRef]

3. Gomez, J.; Lanzolla, G.; Maicas, J.P. The role of industry dynamics in the persistence of first mover advantages. Long Range Plan. 2016, 49, 265-281. [CrossRef]

4. Barney, J. Firm resources and sustained competitive advantage. J. Manag. 1991, 17, 99-120. [CrossRef]

5. D'aveni, R.A.; Ravenscraft, D.J. Economies of integration versus bureaucracy costs: Does vertical integration improve performance? Acad. Manag. J. 1994, 37, 1167-1206. [CrossRef]

6. DiMaggio, P.J.; Powell, W.W. The Iron Cage Revisited: Institutional Isomorphism and Collective Rationality in Organizational Fields. Am. Sociol. Rev. 1983, 48, 147-160. [CrossRef] 
7. Deephouse, D.L. To be different, or to be the same? It's a question (and theory) of strategic balance. Strateg. Manag. J. 1999, 20, 147-166. [CrossRef]

8. Abiodun, T.S. An Examination of the Relationships between Different Types of Innovation and Firm Performance and the Mediating Effect of Radical and Incremental Innovations on These Relationships. Int. J. Innov. Econ. Dev. 2017, 3, 38-58. [CrossRef]

9. Ettlie, J.E.; Bridges, W.P.; O'keefe, R.D. Organization strategy and structural differences for radical versus incremental innovation. Manag. Sci. 1984, 30, 682-695. [CrossRef]

10. Dewar, R.D.; Dutton, J.E. The adoption of radical and incremental innovations: An empirical analysis. Manag. Sci. 1986, 32, 1422-1433. [CrossRef]

11. Pauwels, K.; Silva-Risso, J.; Srinivasan, S.; Hanssens, D.M. New Products, Sales Promotions, and Firm Value: The Case of the Automobile Industry. J. Mark. 2004, 68, 142-156. [CrossRef]

12. Yun, J.J.; Won, D.; Park, K. Dynamics from open innovation to evolutionary change. J. Open Innov. Technol. Mark. Complex. 2016, 2, 7-22. [CrossRef]

13. Chandler, A.D. Strategy and Structure: Chapters in the History of the American Enterprise; MIT Press: Cambridge, MA, USA, 1962.

14. Porter, M.E. What Is Strategy? Harv. Bus. Rev. 1996, 74, 61-78.

15. Zott, C.; Amit, R. Business model design: An activity system perspective. Long Range Plan. 2010, 43, $216-226$. [CrossRef]

16. Oliver, C. Sustainable competitive advantage: Combining institutional and resource- based views. Strateg. Manag. J. 1997, 18, 697-713. [CrossRef]

17. Durand, R.; Grant, R.M.; Madsen, T.L.; Zhao, E.Y.; Fisher, G.; Lounsbury, M.; Miller, D. Optimal distinctiveness: Broadening the interface between institutional theory and strategic management. Strateg. Manag. J. 2017, 38, 93-113.

18. Kim, C.Y.; Lim, M.S.; Yoo, J.W. Ambidexterity in External Knowledge Search Strategies and Innovation Performance: Mediating Role of Balanced Innovation and Moderating Role of Absorptive Capacity. Sustainability 2019, 11, 5111. [CrossRef]

19. Buchko, A. Institutionalization, Coercive Isomorphism, and the Homogeneity of Strategy. Adv. Bus. Res. 2011, 2, 27-45.

20. Baum, J.A.C.; Mezias, S.J. Localized Competition and Organizational Failure in the Manhattan Hotel Industry, 1898-1990. Adm. Sci. Q. 1992, 37, 580-604. [CrossRef]

21. Baum, J.A.C.; Singh, J.V. Organizational Niches and the Dynamics of Organizational Founding. Organ. Sci. 1994, 5, 483-501. [CrossRef]

22. Wernerfelt, B. A resource-based view of the firm. Strateg. Manag. J. 1984, 5, 171-180. [CrossRef]

23. Peteraf, M.A. The cornerstones of competitive advantage: A resource-based view. Strateg. Manag. J. 1993, 14, 179-191. [CrossRef]

24. Prahalad, C.K.; Hamel, G.P. The Core Competence of the Corporation. Harv. Bus. Rev. 1990, 79-91. [CrossRef]

25. Rumelt, R.P. Theory, Strategy, and Entrepreneurship. In Handbook of Entrepreneurship Research; Alvarez, S.A., Agarwal, R., Sorenson, O., Eds.; International Handbook Series on Entrepreneurship, Volume 2; Springer: Boston, MA, USA, 2005.

26. Reed, R.; DeFillippi, R.J. Causal ambiguity, barriers to imitation, and sustainable competitive advantage. Acad. Manag. Rev. 1990, 15, 88-102. [CrossRef]

27. D'Aveni, R.A.; Veliyath, R. Hypercompetition: Managing the Dynamics of Strategic Maneuvering. Acad. Manag. Rev. 1996, 21, 291-294.

28. Miller, D. Nonconformity in Competitive Repertoires. Acad. Manag. Proc. 1995, 1995, 256-260. [CrossRef]

29. Deephouse, D.L. Does isomorphism legitimate? Acad. Manag. J. 1996, 39, 1024-1039. [CrossRef]

30. Geletkanycz, M.A.; Hambrick, D.C. The External Ties of Top Executives: Implications for Strategic Choice and Performance. Adm. Sci. Q. 1997, 42, 654-681. [CrossRef]

31. Finkelstein, S.; Hambrick, D.C. Top-Management-Team Tenure and Organizational Outcomes: The Moderating Role of Managerial Discretion. Adm. Sci. Q. 1990, 35, 484-503. [CrossRef]

32. Shi, W.; Pathak, S.; Song, L.J.; Hoskisson, R.E. The adoption of chief diversity officers among S\&P 500 firms: Institutional, resource dependence, and upper echelons accounts. Hum. Resour. Manag. 2018, 57, 83-96.

33. Martínez-Ferrero, J.; García-Sánchez, I.M. Coercive, normative and mimetic isomorphism as determinants of the voluntary assurance of sustainability reports. Int. Bus. Rev. 2017, 26, 102-118. [CrossRef] 
34. Suchman, M. Managing Legitimacy: Strategic and Institutional Approaches. Acad. Manag. J. 1995, 20, 571-610.

35. Baum, J.A.C.; Oliver, C. Institutional Linkages and Organizational Mortality. Adm. Sci. Q. 1991, 36, 187-218. [CrossRef]

36. McKelvey, B.; Aldrich, H. Populations, natural selection, and applied organizational science. Adm. Sci. Q. 1983, 28, 101-128. [CrossRef]

37. Han, S.K. Mimetic isomorphism and its effect on the audit services market. Soc. Forces 1994, 73, $637-664$. [CrossRef]

38. Mizruchi, M.S.; Fein, L.C. The Social Construction of Organizational Knowledge: A Study of the Uses of Coercive, Mimetic, and Normative Isomorphism. Adm. Sci. Q. 1999, 44, 653-683. [CrossRef]

39. Tingling, P.; Parent, M. Mimetic Isomorphism and Technology Evaluation: Does Imitation Transcend Judgment? J. Assoc. Inf. Syst. 2002, 3, 113-143. [CrossRef]

40. Durand, R.; Kremp, P.A. Classical deviation: Organizational and individual status as antecedents of conformity. Acad. Manag. J. 2016, 59, 65-89. [CrossRef]

41. Philippe, D.; Durand, R. The impact of norm-conforming behaviors on firm reputation. Strateg. Manag. J. 2011, 32, 969-993. [CrossRef]

42. Chang, Y.M.; Chen, H.Y.; Wang, L.F.; Wu, S.J. Corporate social responsibility and international competition: A welfare analysis. Rev. Int. Econ. 2014, 22, 625-638. [CrossRef]

43. Deephouse, D.L.; Suchman, M. Legitimacy in Organizational Institutionalism. In The Sage Handbook of Organizational Institutionalism; SAGE Publications: Los Angeles, CA, USA, 2008.

44. Cobb, J.A.; Wry, T.; Zhao, E.Y. Funding Financial Inclusion: Institutional Logics and the Contextual Contingency of Funding for Microfinance Organizations. Acad. Manag. J. 2016, 59, 2103-2131. [CrossRef]

45. Durand, R.; Paolella, L. Category stretching: Reorienting research on categories in strategy, entrepreneurship, and organization theory. J. Manag. Stud. 2013, 50, 1100-1123. [CrossRef]

46. Das, T.K.; Teng, B.S. A resource-based theory of strategic alliances. J. Manag. 2000, 26, 31-61. [CrossRef]

47. Roberts, P.W.; Amit, R. The dynamics of innovative activity and competitive advantage: The case of Australian retail banking, 1981 to 1995. Organ. Sci. 2003, 14, 107-122. [CrossRef]

48. Basdeo, D.K.; Smith, K.G.; Grimm, C.M.; Rindova, V.P.; Derfus, P.J. The impact of market actions on firm reputation. Strateg. Manag. J. 2006, 27, 1205-1219. [CrossRef]

49. Pontikes, E.G. Two sides of the same coin: How ambiguous classification affects multiple audiences' evaluations. Adm. Sci. Q. 2012, 57, 81-118. [CrossRef]

50. Wry, T.; Lounsbury, M.; Jennings, P.D. Hybrid vigor: Securing venture capital by spanning categories in nanotechnology. Acad. Manag. J. 2014, 57, 1309-1333. [CrossRef]

51. Cho, Y.A.; Jeon, S.B.; Kim, I.C.; Han, K.J.; Choi, H.S.; Park, C.B.; Oh, Y.S. The New Growth Paradigm and Industrial Policy Implications; Korea Institute for Industrial Economics and Trade: Seoul, Korea, 2010.

52. Park, S.O.; Koo, Y. Innovation-driven cluster development strategies in Korea. Eur. Econ. Rev. 2013, 5, 1-17.

53. Science and Technology Policy Institute. Report on the Korean Innovation Survey 2014: Manufacturing Sector; Science and Technology Policy Institute: Seoul, Korea, 2014.

54. Kim, C.; Yoo, J. Organizational ambidexterity based on firms' external search behaviors. Korean J. Bus. Admin. 2018, 31, 1-26. [CrossRef]

55. Bowen, D.E.; Siehl, C.; Schneider, B.A. Framework for Analyzing Customer Service Orientations in Manufacturing. Acad. Manag. Rev. 1989, 14, 75-95. [CrossRef]

56. Dess, G.G.; Beard, D.W. Dimensions of organizational task environments. Adm. Sci. Q. 1984, $29,52-73$. [CrossRef]

57. Aldrich, H.E. Organizations and Environments. Adm. Sci. Q. 1979, 24, 320-326. [CrossRef]

58. Andrevski, G.; Richard, O.C.; Shaw, J.D.; Ferrier, W.J. Racial diversity and firm performance: The mediating role of competitive intensity. J. Manag. 2014, 40, 820-844. [CrossRef]

59. Kim, K.; Li, F.; Yoo, J.W.; Kim, C.Y. The Relationships among Environments, External Knowledge Acquisition, and Innovation. Sustainability 2020, 12, 5541. [CrossRef]

60. Keats, B.W.; Hitt, M.A. A Causal Model of Linkages among Environmental Dimensions, Macro Organizational Characteristics, and Performance. Acad. Manag. J. 1988, 31, 570-598.

61. Aragon-Correa, J.A.; Sharma, S. A Contingent Resource-based View of Proactive Corporate Environmental Strategy. Acad. Manag. Rev. 2003, 28, 71-88. [CrossRef] 
62. Nelson, R.R.; Winter, S.G. An Evolutionary Theory of Economic Change; The Belknap Press of Harvard University Press: Cambridge, MA, USA, 1982.

63. Wiggins, R.R.; Ruefli, T.W. Schumpeter's ghost: Is hypercompetition making the best of times shorter? Strateg. Manag. J. 2005, 26, 887-911. [CrossRef]

64. Yoo, J.W.; Kim, J.I. The effects of entrepreneurial orientation and environmental uncertainty on Korean technology firms' R and D investment. J. Open Innov. Technol. Mark. Complex. 2019, 5, 29. [CrossRef]

65. Majumdar, S.K.; Marcus, A.A. Rules versus discretion: The productivity consequences of flexible regulation. Acad. Manag. J. 2001, 44, 170-179.

66. Rothaermel, F.T.; Alexandre, M.T. Ambidexterity in technology sourcing: The moderating role of absorptive capacity. Organ. Sci. 2009, 20, 759-780. [CrossRef]

67. Miller, D.; Breton-Miller, I.L.; Lester, R.H. Family Firm Governance, Strategic Conformity, and Performance: Institutional vs. Strategic Perspectives. Organ. Sci. 2013, 24, 189-209. [CrossRef]

68. Koske, N.C.; Yegon, J.C. Strategic conformity and financial distress among listed firms in Nairobi Securities Exchange. Int. J. Econ. Commer. Manag. 2017, 5, 19-36.

69. Lawless, M.W.; Finch, L.K. Choice and determinism: A test of Hrebiniak and Joyce's framework on strategy environment fit. Strateg. Manag. J. 1989, 10, 351-365. [CrossRef]

70. Chen, X. Antecedents of Technological Diversification: A Resource Dependence Logic. J. Open Innov. Technol. Mark. Complex. 2019, 5, 80. [CrossRef]

71. Jansen, J.J.P.; Van Den Bosch, F.A.J.; Volberda, H.W. Exploratory Innovation, Exploitative Innovation, and Performance: Effects of Organizational Antecedents and Environmental Moderators. Manag. Sci. 2006, 52, 1661-1674. [CrossRef]

72. Lubatkin, M.H.; Simsek, Z.; Ling, Y.; Veiga, J.F. Ambidexterity and performance in small-to medium-sized firms: The pivotal role of top management team behavioral integration. J. Manag. 2006, 32, 646-672. [CrossRef]

73. Raisch, S.; Birkinshaw, J. Organizational ambidexterity: Antecedents, outcomes, and moderators. J. Manag. 2008, 34, 375-409. [CrossRef]

74. Bauer, D.J.; Curran, P.J. Probing interactions in fixed and multilevel regression: Inferential and graphical techniques. Multivar. Behav. Res. 2005, 40, 373-400. [CrossRef] [PubMed]

75. Hayes, A.F. Introduction to Mediation, Moderation, and Conditional Process Analysis, 2nd ed.; Guilford Press: New York, NY, USA, 2015.

76. Lovas, B.; Ghoshal, S. Strategy as Guided Evolution. Strateg. Manag. J. 2000, 21, 875-896.

77. Yun, J.J. How do we conquer the growth limits of capitalism? Schumpeterian Dynamics of Open Innovation. J. Open Innov. Technol. Mark. Complex. 2015, 1, 17-20. [CrossRef]

Publisher's Note: MDPI stays neutral with regard to jurisdictional claims in published maps and institutional affiliations.

(C) 2020 by the authors. Licensee MDPI, Basel, Switzerland. This article is an open access article distributed under the terms and conditions of the Creative Commons Attribution (CC BY) license (http://creativecommons.org/licenses/by/4.0/). 